\title{
Evaluation of the Antibacterial Activity of Bark Extracts from Anadenanthera colubrine (Vell.) Brenan (Fabaceae Lindl)
}

\author{
Aneli Bernart Vannini, Rosa Cristina Gallassini Tonini, Tchonatan Carles Sturn, Sideney Becker \\ Onofre, Franciele Aní Caovilla Follador, Gisele Arruda
}

\begin{abstract}
The use of natural products for medicinal purposes is the most ancient practice of mankind for the cure, prevention and treatment of diseases, because they are a major source of biologically active compounds. Plants have a secondary metabolism that allows them to produce and store compounds of varied chemical nature; these are distributed differently among the taxonomic groups, have varied biological properties and ecological functions, and are characterized by their different uses and applications, such as in medicines, insecticides, herbicides and perfumes. They are also called natural products. Plants represent an endless source of metabolites that are biologically active and are an important ally of humans in their search for new molecules. This study evaluated the antibacterial activity of two hydro-alcoholic extracts from the bark of Anadenanthera colubrina. For the antibiosis essays, the extracts were diffused into agar and tested against two microorganisms, Escherichia coli and Staphylococcus aureus. Discs of filter paper (5 $\mathbf{~ m m}$ in diameter) were saturated with different concentrations of the extracts and employed. Both extracts showed antimicrobial activity against $E$. coli and $S$. aureus; the extract obtained by allowing the solution to rest was more effective at inhibiting growth. The Minimal Inhibitory Concentration for both extracts was $\mathbf{5 0 \%}$, which caused inhibition halos of $11.21 \mathrm{~mm}(E$. coli) and 10.05 $\mathrm{mm}(\mathrm{S}$. aureu $)$. The rested extract, at a concentration of $50 \%$, produced inhibition halos that were $13.05 \mathrm{~mm}(E$. coli) and $17.45 \mathrm{~mm}$ (S. aureus).
\end{abstract}

Index Terms - Medicinal plants, Antimicrobial, Infections, Therapeutics.

\section{INTRODUCTION}

The use of natural products for medicinal purposes is the most ancient practice of mankind for the cure, prevention and treatment of diseases[1], because they are a major source of biologically active compounds[2]. In Brazil, the use of popular phytotherapeutic products has its roots predominantly in the Amerindian, African and European

Aneli Bernart Vannini, Department of Biology, University of Paranaense, Francisco Beltrão, Brasil

Rosa Cristina Gallassini Tonini, Department of Biology, University of Paranaense, Francisco Beltrão, Brasil

Tchonatan Carles Sturn, Department of Biology, University of Paranaense, Francisco Beltrão, Brasil

Sideney Becker Onofre, Department of Biology, Two-Faced Educational Faculty, Francisco Beltrão, Brasil

Franciele Aní Caovilla Follador, Department of Health Sciences, State University of Western Paraná, Francisco Beltrão, Brasil

Gisele Arruda, Departmente of Health Sciences, State University of Western Paraná, Francisco Beltrão, Brasil cultures[3]. Despite major advances in medicine since the $20^{\text {th }}$ century, plants still contribute greatly in the aid and treatment of illnesses. In developing countries such as Brazil, according to the World Health Organization (WHO), it is estimated that $65-80 \%$ of the population depends on popular phytotherapy for basic health care[4]. Tradition and availability are the major reasons for the use of plants[1]. For this reason, phytotherapy is a viable alternative for most developing countries that face socio-economical shortages[5]

Plants have a secondary metabolism that allows them to produce and store compounds of varied chemical nature; these are distributed differently among the taxonomic groups, have varied biological properties and ecological functions, and are characterized by their different uses and applications, such as in medicines, insecticides, herbicides, perfumes, and stains. They are also called natural products[6].

The use of plants by urban populations of rural origin is based on knowledge of the natural environment, as well as by the social relations these people have in their communities. Many vegetal products and their uses are currently indispensable to urban populations of rural origin where there are community members that know how to domesticate and manipulate the healing properties of plants[7]. The culture surrounding the use and cultivation of medicinal plants is an important local resource for the health and sustainability of urban environments[8].

Among the plant families used in popular phytotherapy is the Fabaceae, which contains Anadenanthera colubrina (Vell.) Brenan. Known as white angico, this species has high concentrations of tannins in its bark $[9,10]$.

In daily life, the bark of $A$. colubrina is used for staining fishing nets by the fishermen of Ilha Grande[11], tannins from this species are used in the production of drugs[12] and its wood is used in construction[13]. As for its ecological importance Oliveira[11] states it is possible that the high dominance and relative density of this species on Ilha Grande could contribute to the restoration of the soil of plantations in this region.

This work evaluated the antimicrobial activity of extracts from the bark of Anadenanthera colubrina (Vell) Brenan against the pathogenic microorganisms Escherichia coliATCC: 25923 and Staphylococcus aureus - ATCC: 25922. 


\section{MATERIALS AND METHODS}

\section{a. Collection of Material}

Aerial parts (inner bark) of Anadenanthera colubrina (Vell.) Brenan were collected in the town of Francisco Beltrão (Paraná), in June 2012. The collections were identified using literature and archived (number 152A) at the Botany Laboratory at Paranaense University, Campus of Francisco Beltrão, PR. The collection of the material was authorized by the Brazilian Institute of the Environment and Renewable Resources (IBAMA) under the permit number 13234-2 of 08.01.2006.

\section{b. Obtainment of Extracts}

For the preparation of the hydro-alcoholic extracts, the orientation of process A from Pharmacopéia dos Estados Unidos do Brasil was followed[14], which was further adapted by Younes et al.[15]. The inner bark of the trunk of Anadenanthera colubrina (Vell.) Brenan was removed and dried at room temperature and then in a stove at $50^{\circ} \mathrm{C}$ until a uniform level of humidity was achieved. The material was ground and mixed with a hydro-alcoholic solution $(70 \%$ ethanol) at a proportion of $20 \%\left(\mathrm{~m}^{\left.-\mathrm{v}^{-1}\right)}\right.$. The solution was then divided into two parts, "A" and "B". Solution "A" was heated to $60^{\circ} \mathrm{C}$ for $2 \mathrm{~h}$ and $30 \mathrm{~min}$ and further concentrated using a rot evaporator until $20 \%$ of the initial extract was obtained. The final evaporate was called the heated extract (Eh). Solution "B" was stored at rest in the dark, at room temperature, for 10 days, and then filtered. From the filtrate, a concentrated extract equal to $20 \%$ of the initial extract was obtained using a rot evaporator; this extract was called the rested extract $(\mathrm{Er})$.

\section{c. Obtainment of the dilutions}

The extracts were evaluated using the method of Kirby and Bauer[16] and the culture medium was composed of Mueller-Hinton agar supplemented with $2 \%$ glucose. Bacterial suspensions were prepared in sterile physiological solutions and then adjusted to 0.5 on the McFarland scale, which corresponds to approximately $1.5 \times 10^{6} \mathrm{UFC} \mathrm{mL}^{-1}$. These were made from the strains Escherichia coli ATCC 25922 (beta-lactamase negative) and Staphylococcus aureus ATCC 25923 (susceptible to oxacillin and penicillin) that were obtained from the Microbiology Laboratory at Paranaense University (Campus of Francisco Beltrão).

\section{d. Preparation of the dilutions of the extracts}

Graduated tubes numbered from 1 to 10 were used for the different concentrations of the two extracts. Dimethylsulfoxide (DMSO) was employed as a solvent. The concentrations prepared of each extract were: $100 ; 50 ; 25$; $12.5 ; 6.25 ; 3.12 ; 1.56 ; 0.78 ; 0.39$ and $0.19 \%$. These dilutions were stored in amber flasks for future evaluations.

\section{e. Preparation of the paper discs}

Paper discs (6 $\mathrm{mm}$ diameter) were saturated with the dilutions at the concentrations of $100 ; 50 ; 25 ; 12.5 ; 6.25$; $3.12 ; 1.56 ; 0.78 ; 0.39$ and $0.19 \%$. The saturated discs were kept in a laminar flow chamber while the excess solvent evaporated.

\section{f. Disc diffusion assay}

The bacterial suspensions were inoculated onto plates containing Mueller-Hinton agar using a swab. The saturated discs were then transferred to the inoculated media. The plates were incubated at $35 \pm 1^{\circ} \mathrm{C}$ for 24 hours. After this period, they were evaluated for the presence of inhibition halos (measured in $\mathrm{mm}$ ). The diameters of the halos were interpreted based on the criteria published in Clinical Laboratory Standards International - CLSI[17]. The Minimal Inhibitory Concentration (MIC) was considered as the lowest extract concentration capable of inhibiting bacterial development.

\section{g. Statistical analysis}

All of the assays were tested in triplicate. The data obtained were subjected to analysis of variance, according to the rules of ANOVA. The significant differences between the means were determined by Tukey's test.

\section{RESULTS AND DISCUSSION}

The results of the evaluation of the two extracts obtained from the inner bark of the trunk of Anadenanthera colubrina (Vell.) Brenan are presented in Table I. These data show the antimicrobial activity of the two extracts evaluated, represented by their Minimal Inhibitory Concentration (MIC) of $50 \%$.

Table I. Minimal Inhibitory Concentration (MIC) of 50\% of the two extracts of Anadenanthera colubrina (Vell.) Brenan (white angico), which represents the antimicrobial activity against the pathogenic microorganisms Escherichia coli and Staphylococcus aureus.

\begin{tabular}{lccc}
\hline Bactenum & \multicolumn{2}{c}{ Extracts Evaluated $(50 \%)$} & Standard $^{\sharp}$ \\
\cline { 2 - 4 } & Eh & Er & Chloramphenicol $^{-1}$ \\
\hline Escherichiacoli & $11.21 \pm 0.90 \mathrm{Ba}$ & $13.05 \pm 2.10 \mathrm{Ab}$ & $18.00 \mathrm{Aa}$ \\
Staphylococcus & $10.40 \pm 1.90 \mathrm{Bb}$ & $17.45 \pm 1.20 \mathrm{Aa}$ & $18.00 \mathrm{Aa}$ \\
aureus & & & \\
\hline
\end{tabular}

Means followed by the same lowercase letter in the same row and the same capital letter in the same column do not differ by Tukey's test at the level of p>0.05. Er - Rested extract after 10 days. Eh Extract heated at $60^{\circ} \mathrm{C}-2 \mathrm{~h}$ and $30 \mathrm{~min}$. \# - Discs of Chloramphenicol at the concentration of $10 \mu \mathrm{g} /$ disc. ${ }^{*}$ Inhibition halos determined in millimeters.

The data referring to the behavior of the two extracts evaluated, shown in Table 1, demonstrate that both hydro-alcoholic extracts of the bark inhibited the in vitro growth of Escherichia coli and Staphylococcus aureus. The rested extract (Er) showed better results against $S$. aureus, which were comparable to chloramphenicol because their inhibition halos did not differ significantly by Tukey's test.

Based on the heated extract data, it was found that the inhibition halo for $E$. coli was $11.21 \pm 0.90 \mathrm{~mm}$ and $10.40 \pm 1.90 \mathrm{~mm}$ for $S$. aureus; these data were not significantly different when compared by Tukey's test (at the level of 5\%) and were significantly inferior to the control that used chloramphenicol, which had an inhibition halo of 18.00 $\mathrm{mm}$.

It was also verified that both extracts presented antimicrobial activity against $E$. coli and $S$. aureus, but the rested extract showed better results than those of the heated 
extract against both pathogenic bacteria. However, the Minimal Inhibitory Concentration (MIC) for both extracts was the concentration of $50 \%$.

These results suggest that the difference could be related to heat, because the metabolites present in the heated extract were exposed to $60^{\circ} \mathrm{C}$. This exposure could have changed the biological properties of the metabolites in the extract, resulting in lower antimicrobial activity. Based on this, it is believed that the difference was due to the methodology used to prepare the extracts.

The results in this work are in accordance with other investigations that have evaluated the antimicrobial properties of extracts of Anadenanthera colubrine. Studies have shown this plant has medicinal properties that are possibly related to the presence of tannins in the inner bark. Anti-inflammatory, healing, depurative, and hemostatic properties are attributed to this chemical group, which is used in the treatment of angina, diarrhea, gonorrhea and ulcerations[18,19,20].

According to Pizzi[21], it is better to use low temperatures to extract tannins because this method allows for the extraction of different kinds of tannins and other active compounds, which increases the biological activity of the extract.

The methodology adopted in this study is consistent with the different methodologies proposed to obtain active metabolites in plants, where one must consider the availability of metabolites in the plant, the plant itself and the ease of obtaining the metabolites, because although a plant might contain hundreds of secondary metabolites only compounds present in high concentrations are generally isolated and studied.

The analysis of active substances is more complex and takes longer, because the compounds that usually produce greater biological effects are present in the plant in lower proportions. For this reason, there is a need for a broader collaboration between chemists and pharmacologists to analyze extracts, especially those where semi-pure extracts, fractions, and then pure compounds are obtained[22,23].

In addition, it is essential to perform a complete analysis of the chemical groups present in an extract as well as their concentrations. Without this data it is not possible to efficiently determine the biological activity of each chemical component of the extract.

Thus, a broad multidisciplinary collaboration is needed to obtain pure compounds endowed with biological effects, in addition to the determination of these compounds by researchers[24].

These results are also in accordance with a study by Mors et al.[25], which found that hydro-alcoholic extracts of this plant species inhibited the growth of $S$. aureus and E. coli using similar assays. Other investigations that had similar result are those of Mors et al.[25] and Gonçalves et al.[26], which showed that alcoholic extracts of $A$. colubrine also inhibited of growth of $S$. aureus and E. coli.

In the present study, the extracts tested had antibacterial activity, especially the hydro-alcoholic extract Er, which was more effective in the control of the Gram-positive bacterium $S$. aureus, compared to the Gram-negative bacterium.

Therefore, the use of extracts obtained from the white angico, Anadenanthera colubrina, is another alternative for the treatment and cure of diseases involving infectious processes where the use of plant products and conventional medications can be an alternative for the improvement of the conditions of life in developing countries, especially when considering the importance of the use of medicinal plants as a therapeutic resource.

\section{CONCLUSION}

According to the results obtained, it was possible to verify that both hydro-alcoholic extracts obtained from the bark of Anadenanthera colubrine exhibit antimicrobial activity against Gram-positive and Gram-negative bacteria.

The extract obtained by allowing the solution to rest $(\mathrm{Er})$ was more efficient than the extract obtained by heating the solution in the inhibition of the bacteria E. coli and S. aureus.

\section{REFERENCES}

[1] V. F. Veiga Junior, et al., "Medicinal plants: safe cure" "Plantas medicinais: cura segura?," Química Nova, Fev. 2005, pp. 519-28.

[2] S. Andrade, et al., "Antiinflammatory and antinociceptive activities of extract, fractions and populnoic acid from bark wood of Austroplenckia populne," Journal of Ethnopharmacology, vol. 109, n. 3, Fev. 2007, pp. 464-71.

[3] E. R. Martins, "Medicinal plants" "Plantas medicinais," 1th ed. ed. Viçosa: Universitária, Jun. 1995, pp. 33-46.

[4] J. B. Calixto, "Efficacy, safety, quality control, marketing and regulatory guidelines for herbal medicines (phytotherapeutic agents),' Brazilian Journal of Medical and Biological Research, vol. 33, n. 2 , Fev. 2000, pp. 179- 89.

[5] J. M. Albuquerque, "Medicinal plants of popular use" "Plantas medicinais de uso popular," 1th ed. ed. Brasília: Ministério da Educação, 1989.

[6] C. Pérez-Urria, et al., "Secondary plant metabolism" "Metabolismo Secundário de Plantas," Reduca, vol. 2, n. 3, Nov. 2009, pp. 119-45.

[7] S. Castelluci, et al., "Plantas medicinais relatadas pela comunidade residente na estação ecológica de Jatai, Município de Luis Antonio/SP: uma abordagem etnobotanica" "Medicinal plants reported by the community living in the ecological station of Jatai, Municipality of Luis Antonio / SP: an ethnobotanical approach," Revista Brasileira de Plantas Medicinais, vol. 3, n. 1, Nov. 2000, pp. 51-60.

[8] J. E. Dias, "The importance of the use of medicinal plants in peripheral communities and their production through urban agriculture" "A importância do uso de plantas medicinais em comunidades de periferia e sua produção através da agricultura urbana," Acta Horticulturae, vol. 569, Mar. 2002, pp. 79-85.

[9] S. Piacentini, et al., "Anadanthoside: a flavanol-3-0- $\beta$-d-xylopyranoside from Anadenanthera macrocarpa," Phytochemistry, vol. 51, n. 2, Jul. 1999, pp. 709-11.

[10] M. T. Gutierrez-Lugo, et al., "Lipoxygenase inhibition by Anadanthoflavone, a new flavonoid from the aerials parts of Anadenanthera colubrine," Planta Medica, vol. 70, n. 2, Mar. 2004, pp. 263-65.

[11] R. R. Oliveira, "Anthropogenic and resulting actions on the structure and composition of the Atlantic forest in Ilha Grande, RJ" "Ação antrópica e resultantes sobre a estrutura e composição da mata atlântica na Ilha Grande, RJ," Rodriguésia, vol, 53, n. 82, 2001, pp33-58.

[12] J. M. Monteiro, et al., "Tannin content in three Sympatric Arboreal Medicinal Species of the Caatinga" "Teor de Taninos em Três Espécies Medicinais Arbóreas Simpátricas da Caatinga," Revista Árvore, vol. 29, n. 6, Ago. 2005, pp 999-1005.

[13] G. Lewis, et al., "Legumes Of The World," 1th ed. ed. Kew, Richmond, Royal Botanic Gardens, 2005.

[14] R. A. Dias da Silva, "Pharmacopoeia of the United States of Brazil" "Pharmacopéia dos Estados Unidos do Brasil," 1th ed. ed. São Paulo: Companhia Editora Nacional, 1929.

[15] R. N. Younes, et al., "Extraction and tracking of new drugs in Brazilian plants" "Extração e rastreamento de novas drogas em plantas brasileiras," Acta Oncológica Brasileira, vol. 20, n. 3, 2000, pp. 15-19.

[16] J. Vandepitte, "Laboratory procedures in clinical bacteriology" "Procedimentos laboratoriais em bacteriologia clínica," OMS. 1th ed. ed. São Paulo: Editora Santos, 1994.

[17] Clinical Laboratory Standards International (CLSI), "Performance standards for antimicrobial susceptibility testing; tenth informational supplement M100-S10," Wayne, PA: CLSI, 2000. 


\section{Evaluation of the Antibacterial Activity of Bark Extracts from Anadenanthera colubrine (Vell.) Brenan (Fabaceae Lindl)}

[18] M. Pio Corrêa, "Dictionary of useful plants of Brazil and exotic cultivated" "Dicionário das plantas úteis do Brasil e das exóticas cultivadas," 1th ed. ed. Rio de Janeiro: Imprensa Nacional, 1978.

[19] A. Scalbert, "Antimicrobial properties of tannins," Phytochemistry, vol. 30, n. 12, Abr. 1991, pp. 3875-3883.

[20] C. M. O. Simões, et al., "Pharmacognosy: from plant to medicine" "Farmacognosia: da planta ao medicamento," 1th ed. ed. Porto Alegre: Editora da Universidade Federal do Rio Grande do Sul, 2001.

[21] A. Pizzi, "Advanced wood adhesives technology," 1th ed. ed. New York: Marcell Deckker, 1994.

[22] O. L. Ugaz, "Phytochemical Research: the natural products study methods" "Investigacion Fitoquimica: métodos el estúdio de produtos naturales," 2th ed. ed. Peru: Pontifícia Universidade Católica Del Peru; Fondo Editorial, 1994

[23] W. B. Dunn, D. I. Ellis, "Metabolic: current analytical platforms and methodologies," Trends in Analytical Chemistry, vol. 24, n. 4, 2005 pp. 285-294

[24] A. S. Santos, S. M. Alves, F. S. Figueiredo, "Description of systems for the extraction of essential oils" "Descrição de sistemas de método de extração de óleos essenciais," 1th ed. ed. Belém: Comunicado Técnico, 2004

[25] W. B. Mors, et al., "Medicinal plants of Brazil," 1th ed. ed. Michigan Reference Publications, 2000

[26] A. L. Gonçalves, et al., "Comparative study of the antimicrobial activity of extracts from some native trees" "Estudo comparativo da atividade antimicrobiana de extratos de algumas árvores nativas," Arquivos do Instituto Biológico, vol. 72, n. 3, Jul/Set. 2005, pp. 353-58

Aneli Bernart Vannini is a full professor at the Universidade Paranaense. Master in Chemistry.

Rosa Cristina Gallassini Tonini is a biologist, holds a master's degree in Environmental Engineering and holds a doctorate in Comparative Biology

Tchonatan Carles Sturn is Pharmacist and participated in the project while graduating.

Sideney Becker Onofre is a professor at two Brazilian universities, where he works in the area of Bioprocesses and Biotechnology. It develops research in the areas of Biotechnology Applied to the Environment, Agroindustry and Technological Development, with the reuse of agroindustrial residues. He is currently the editor-in-chief of the Journal of Biology and Health of Unisep - Biology \& Health Journal - ISSN 1982-2774.

Franciele Aní Caovilla Follador is a Teacher and $\mathrm{PhD}$ at 17 years of the State University of Western Paraná. Director of the Health Sciences Center. Has several publications in this area.

Gisele Arruda is Teacher at the State University of Western Paraná. He has a Master's Degree in Biochemical Sciences and a PhD in Comparative Biology. Has several publications in this area. Coordinator of the research project with mutagens, genetics and cancer. 